\title{
Essential oil from two populations of Echinodorus grandiflorus (Cham. \& Schltdl.) Micheli (Chapéu de couro)
}

\author{
DANIEL S. PIMENTA ${ }^{1,2}$, MARIA RAQUEL FIGUEIREDO ${ }^{1}$ \\ and MARIA AUXILIADORA C. KAPLAN ${ }^{3 *}$ \\ ${ }^{1}$ Laboratório de Produtos Naturais, PN3, Far-Manguinhos, FIOCRUZ \\ Rua Sizenando Nabuco, 100, 21041-250 Rio de Janeiro, RJ, Brasil \\ ${ }^{2}$ Departamento de Botânica, Instituto de Ciências Biológicas, UFJF, Campus Universitário \\ 36036-330 Juiz de Fora, MG, Brasil \\ ${ }^{3}$ Núcleo de Pesquisas de Produtos Naturais, UFRJ, Cidade Universitária \\ 21941-900 Rio de Janeiro, RJ, Brasil \\ Manuscript received on July 27, 2005; accepted for publication on May 2, 2006; \\ contributed by MARIA AUXILIADORA C. KAPLAN*
}

\begin{abstract}
Analysis by Gas Chromatography and Gas Chromatography/Mass Spectrometry of the essential oils obtained from leaves of Echinodorus grandiflorus ("Chapéu de couro") from two different populations (Big Leaves and Small Leaves), collected monthly between September 1998 and December 1999 revealed 17 components. Phytol was the major constituent for both populations. The main sesquiterpene representatives are $(E)$-caryophyllene, $\alpha$-humulene and $(E)$-nerolidol.
\end{abstract}

Key words: Echinodorus grandiflorus, Alismataceae, essential oil, sesquiterpenes, diterpenes.

\section{INTRODUCTION}

Alismataceae is a primitive monocotyledonous family comprising 11 genera and 75 species occurring in tropical, subtropical and subtemperate regions in the Eastern as well as the Western Hemisphere (Crow 2003). These plants are aquatic or semi-aquatic herbs with milky sap. Of the two largest genera, Echinodorus is restricted to the neotropics, native in tropical America and it is formed by 26 species that occur from northern United States to Patagonia (Haynes and Nielsen 1994). In Brazil E. grandiflorus and E. macrophyllus are popularly known as "chapéu de couro". These plants have been used in the folk medicine as

*Member Academia Brasileira de Ciências Correspondence to: Daniel Sales Pimenta E-mail: dsp@icb.ufjf.br anti-inflammatory and diuretic. The chemical profile of Echinodorus species is represented basically by terpenoids (Manns and Hartmann 1993, Tanaka et al. 1997, Costa et al. 1999, Kobayashi et al. 2000a, b).

This paper aims to describe the leaf essential oils from two populations of E. grandiflorus.

\section{MATERIALS AND METHODS}

\section{Collection of Plant Material}

Leaves of E. grandiflorus were collected monthly from September 1998 to December 1999, (except in February and July) in Tanguá, Rio de Janeiro State, Brazil. The plants have been cultivated in two different places in the area resulting in two morphologically distinct populations: one showing exuberant big leaves (BL), growing on the sandy 
bed of an irrigation ditch and the other, with scrubby small leaves (SL), occurring on a clayish bank formerly used as a decantation lake for fluorite mining residues. The mean of leaf dry weight along the fourteen months of collection was $4.0 \mathrm{~g}$ and $1.2 \mathrm{~g}$ respectively for BL and SL. Leaves of the specimens from the two populations were always harvested in the morning by 10.00 o'clock. The botanical materials were identified by the botanist Dr. Erika Santos Guimarães as Echinodorus grandiflorus (Chamisso and Schlechtendal) Micheli, and the vouchers are found at the Herbarium CESJ, Universidade Federal de Juiz de Fora, Juiz de Fora, MG, under the register number 30.707.

\section{ISOLATION OF THE OILS}

About $3.00 \mathrm{~h}$ after the collection the freshly picked leaves were hydrodistilled in a Clevenger-type apparatus (Gottlieb and Magalhães 1960) for 1.30h. The obtained oils were stored at $-18^{\circ} \mathrm{C}$ to be analyzed.

\section{Gas Chromatographic Analyses, GC}

Capillary gas chromatography was performed using a Hewlett-Packard 6890 gas chromatograph; fused silica capillary column HP-5 (5\% diphenyl and $95 \%$ dimethylpolysyloxane, $60 \mathrm{~m} \times 0,25 \mathrm{~mm}$, $0,25 \mu \mathrm{m}$ film thickness); helium as carrier gas; and temperature programming from $70^{\circ} \mathrm{C}$ to $290^{\circ} \mathrm{C}$ $\left(2^{\circ} \mathrm{C} / \mathrm{min}\right)$; injector temperature $270^{\circ} \mathrm{C}$ and detector temperature $300^{\circ} \mathrm{C}$.

\section{Gas Chromatography / Mass Spectrometry, GC/MS}

This analysis was carried out using a HewlettPackard 6890 gas chromatograph equipped with a fused silica capillary column (HP-5, 30m $\times$ $0.25 \mathrm{~mm}, 0.25 \mu \mathrm{m}$ film thickness), helium as carrier gas with a flow rate $1.0 \mathrm{ml} / \mathrm{min}$; temperature programming from $70^{\circ} \mathrm{C}$ to $290^{\circ} \mathrm{C}\left(2^{\circ} \mathrm{C} / \mathrm{min}\right)$, coupled to a Hewlett-Packard 5972 mass spectrometer. The MS operating parameters were: $70 \mathrm{eV}$, ion source $250^{\circ} \mathrm{C}$ equipped with $\mathrm{EI}$.

\section{IDENTIFICATION OF THE OIL COMPONENTS}

The compound identifications were carried out by comparison of their retention indices (RI) with literature values; and the MS data with those from Wiley 275.1 mass spectral data base besides literature records (Adams 1995).

\section{RETENTION INDICES (RI)}

These indices were calculated using a GC data of a homologous series of saturated aliphatic hydrocarbons within $\mathrm{C} 8$ to $\mathrm{C} 22$, performed at the same column and conditions as used in the GC analysis for the essential oils.

\section{RESULTS AND DISCUSSION}

The identified constituents of E. grandiflorus essential oils for the two analyzed populations (BL and SL) are shown in Tables I and II respectively, as well as with their percentage monthly recorded in GC analyses for the period September 1998 to December 1999, except in February and July. Both tables also show for each compound the mean percentage of oils, the mean retention time (RT) and the mean calculated retention indices (RI) as well as the literature RI recorded. Considering the relative area percentage, the total identified compounds was $58.9 \%$ for the BL and $60.3 \%$ for SL populations, being $39.9 \% / 32.0 \%$ due to mono- and sesquiterpenes and $19.0 \% / 28.3 \%$ to diterpenes for BL and SL populations respectively. Analyses of these tables show for the two populations phytol as the major oil constituent. The other significant sesquiterpene oil components are $(E)$-caryophyllene, $(E)$-nerolidol and $\alpha$-humulene. Figures 1a and $1 \mathrm{~b}$ shows the variability of the major sesquiterpene constituents from September 1998 to December 1999, for the two populations and $(E)$-caryophyllene showed to be the most representative product although for the BL population it has been closely followed by $(E)$-nerolidol.

The relative percentages of diterpenes in the $E$. grandiflorus essential oils for the two populations (Figures $2 \mathrm{a}$ and $2 \mathrm{~b}$ ) besides the production of huge 
TABLE I

Identified constituents of $E$. grandiflorus essential oils from BL-population with their percentage monthly recorded in GC-analysis for the period September 1998 to December 1999, together their mean percentage of oil $(O)$, the mean retention time $(\mathrm{RT})$ and the mean calculated retention indices (CRI) as well as the literature RI (LRI).

\begin{tabular}{|c|c|c|c|c|c|c|c|c|c|c|c|c|c|c|c|c|c|c|c|}
\hline & Constituents & Sept & Oct & Nov & Dec & Jan & Mar & Apr & Mai & Jun & Aug & Sept & Oct & Nov & Dec & $\mathrm{O}$ & RT & CRI & LRI \\
\hline 1 & linalool & 0.0 & 0.4 & 0.6 & 1.6 & 1.2 & 0.9 & 0.0 & 0.5 & 1.4 & 1.4 & 1.0 & 1.2 & 0.0 & 0.2 & 0.7 & 15.5 & 1104 & 1098 \\
\hline 2 & dihydroedulan & 3.3 & 0.9 & 1.6 & 2.1 & 3.7 & 3.1 & 0.0 & 1.7 & 1.3 & 1.1 & 0.9 & 0.8 & 0.6 & 0.9 & 1.5 & 26.7 & 1300 & - \\
\hline 3 & (E)-caryophyllene & 20.2 & 20.3 & 14.8 & 13.5 & 10.5 & 10.9 & 0.4 & 0.3 & 21.1 & 18.6 & 10.3 & 14.2 & 0.0 & 2.0 & 11.5 & 34.3 & 1428 & 1418 \\
\hline 4 & alpha humulene & 9.6 & 7.5 & 5.7 & 5.6 & 5.6 & 5.5 & 0.0 & 0.3 & 9.0 & 6.8 & 4.0 & 5.6 & 0.7 & 1.8 & 4.9 & 36.2 & 1460 & 1454 \\
\hline 5 & $(E)$-farnesene & 0.0 & 0.7 & 0.7 & 1.1 & 1.1 & 0.8 & 0.3 & 1.9 & 2.2 & 0.7 & 0.9 & 0.7 & 0.0 & 2.4 & 1.0 & 37.8 & 1487 & 1458 \\
\hline 6 & beta selinene & 0.0 & 0.4 & 0.3 & 0.4 & 0.6 & 0.0 & 0.5 & 0.4 & 0.8 & 0.4 & 0.3 & 0.4 & 0.0 & 0.7 & 0.4 & 38.6 & 1501 & 1485 \\
\hline 7 & alpha farnesene & 0.0 & 0.8 & 1.0 & 0.5 & 1.6 & 1.5 & 0.9 & 0.5 & 0.2 & 0.4 & 0.6 & 1.1 & 8.1 & 8.2 & 1.8 & 39.8 & 1522 & 1508 \\
\hline 8 & delta cadinene & 0.0 & 0.0 & 0.0 & 0.6 & 0.6 & 0.5 & 0.0 & 0.5 & 0.8 & 0.4 & 0.3 & 0.5 & 1.9 & 0.5 & 0.5 & 40.2 & 1529 & 1513 \\
\hline 9 & $(E)$-nerolidol & 21.0 & 9.7 & 7.2 & 6.7 & 8.6 & 9.9 & 6.6 & 3.4 & 7.8 & 5.3 & 4.6 & 7.9 & 11.8 & 2.1 & 8.2 & 42.5 & 1570 & 1564 \\
\hline 10 & caryophyllene oxide & 13.3 & 0.0 & 4.1 & 4.0 & 6.8 & 7.4 & 3.5 & 19.6 & 2.2 & 3.1 & 5.2 & 5.0 & 0.0 & 1.0 & 4.5 & 43.7 & 1591 & 1576 \\
\hline 11 & humulene epoxide & 0.0 & 0.0 & 1.1 & 0.9 & 1.5 & 1.5 & 0.6 & 4.2 & 0.7 & 0.8 & 1.0 & 1.2 & 0.0 & 0.3 & 1.0 & 45.1 & 1617 & 1581 \\
\hline 12 & bisabolone & 0.0 & 0.3 & 0.3 & 0.2 & 0.0 & 0.4 & 0.3 & 1.4 & 0.4 & 0.0 & 0.2 & 0.3 & 0.7 & 0.3 & 0.3 & 50.5 & 1717 & 1650 \\
\hline 13 & drimenol & 1.5 & 3.9 & 3.8 & 2.6 & 3.9 & 4.9 & 1.3 & 2.0 & 4.4 & 2.4 & 2.4 & 5.3 & 4.2 & 1.6 & 3.1 & 53.2 & 1770 & 1759 \\
\hline 14 & neocembrene & 0.0 & 0.3 & 0.8 & 0.4 & 0.6 & 0.7 & 0.3 & 0.3 & 0.5 & 0.3 & 0.3 & 0.8 & 0.7 & 0.3 & 0.5 & 60.8 & 1924 & 1959 \\
\hline 15 & echinoic acid & 0.0 & 1.1 & 1.9 & 5.1 & 0.9 & 1.6 & 2.6 & 7.6 & 3.1 & 2.1 & 1.0 & 4.1 & 4.6 & 6.9 & 2.9 & 63.1 & 1972 & $* *$ \\
\hline 16 & cembranoid & 0.0 & 1.1 & 1.6 & 5.3 & 0.8 & 1.3 & 10.2 & 2.4 & 1.8 & 1.3 & 1.2 & 0.3 & 0.7 & 4.8 & 2.2 & 69.6 & 2116 & - \\
\hline 17 & phytol & 7.8 & 22.2 & 18.0 & 2.7 & 7.4 & 16.8 & 45.3 & 5.6 & 2.6 & 2.8 & 5.6 & 11.4 & 12.3 & 28.7 & 13.4 & 69.9 & 2123 & **** \\
\hline 18 & $*(1-13)$ & 68.9 & 45.0 & 41.2 & 39.9 & 45.7 & 47.2 & 14.4 & 36.6 & 52.3 & 41.2 & 31.8 & 44.4 & 27.9 & 22.0 & 39.9 & - & - & - \\
\hline 19 & $(14-17)$ & 7.8 & 24.7 & 22.2 & 13.6 & 9.7 & 20.5 & 58.4 & 15.9 & 7.9 & 6.5 & 8.0 & 16.7 & 18.3 & 40.7 & 19.0 & - & - & - \\
\hline 20 & $\begin{array}{l}(1-17) \\
\end{array}$ & 76.7 & 69.7 & 63.4 & 53.5 & 55.4 & 67.7 & 72.8 & 52.5 & 60.2 & 47.7 & 39.8 & 61.1 & 46.2 & 62.7 & 58.9 & - & - & - \\
\hline
\end{tabular}

* 18 = identified mono- and sesquiterpenes (1-13); $19=$ identified diterpenes (14-17); $20=$ identified constituents (1-17). LRI = Adams 1995; ** = Tanaka et al. 1997; **** $=$ (C.M.A. Tanaka, unpublished data).

TABLE II

Identified constituents of $E$. grandiflorus essential oils from SL-population with their percentage monthly recorded in GC-analysis for the period September 1998 to December 1999, together their mean percentage of oil (O), the mean retention time (RT) and the mean calculated retention indices (CRI) as well as the literature RI (LRI).

\begin{tabular}{|c|c|c|c|c|c|c|c|c|c|c|c|c|c|c|c|c|c|c|c|}
\hline & Consti & ept & Oct & Nov & Dec & Jan & Mar & Apr & Mai & Jun & Aug & Sept & Oct & Nov & Dec & $\mathrm{O}$ & RT & CRI & LRI \\
\hline 1 & linalool & 0.0 & 0.8 & 1.3 & 1.1 & 0.3 & 0.9 & 0.5 & 0.3 & 0.5 & 0.3 & 0.5 & 0.7 & 0.7 & 0.0 & 0.6 & 15.5 & 1104 & 1098 \\
\hline 2 & dihydroedulan & 1.2 & 1.1 & 2.6 & 2.5 & 1.2 & 2.8 & 1.2 & 1.2 & 0.8 & 0.7 & 0.6 & 1.2 & 1.3 & 2.0 & 1.4 & 26.7 & 300 & - \\
\hline 3 & (E)-caryophyllene & 7.4 & 18.8 & 20.1 & 8.9 & 5.0 & 9.6 & 3.2 & 1.7 & 9.7 & 6.4 & 10.0 & 4.9 & 15.4 & 0.0 & 8.6 & 34.3 & 1428 & 1418 \\
\hline 4 & alpha humulene & 3.2 & 7.6 & 7.9 & 3.6 & 2.7 & 4.1 & 1.7 & 0.9 & 4.5 & 3.3 & 4.0 & 2.4 & 7.6 & 0.3 & 3.8 & 36.2 & 1460 & 1454 \\
\hline 5 & $(E)$-farnesene & 0.0 & 1.4 & 1.3 & 3.1 & 2.1 & 4.2 & 1.2 & 2.0 & 3.5 & 2.1 & 1.0 & 1.4 & 3.8 & 3.2 & 2.2 & 37.9 & 1489 & 1458 \\
\hline 6 & ta se & 1.9 & 0.8 & 0.7 & 1.6 & 1.0 & 2.2 & 0.6 & 0.5 & 1.6 & 1.1 & 0.5 & 0.6 & 1.7 & 0.6 & 1.1 & 38.6 & 1501 & 1485 \\
\hline 7 & alpha farnesene & 0.0 & 1.3 & 0.8 & 0.7 & 0.3 & 1.3 & 0.4 & 0.2 & 0.2 & 0.6 & 0.2 & 0.4 & 5.0 & 8.4 & 1.4 & 39.8 & 1522 & 1508 \\
\hline 8 & lta cadinene & 0.0 & 0.7 & 0.7 & 0.3 & 0.3 & 0.3 & 0.3 & 0.2 & 0.4 & 0.2 & 0.5 & 0.1 & 1.4 & 0.9 & 0.5 & 40.2 & 1529 & 1513 \\
\hline 9 & (E)-nerolidol & 13.5 & 8.4 & 6.7 & 4.6 & 4.8 & 6.6 & 5.3 & 2.2 & 3.1 & 3.5 & 3.1 & 2.7 & 4.1 & 1.0 & 5.0 & 42.5 & 1570 & 1564 \\
\hline 10 & caryophyllene oxide & 7.2 & 7.3 & 6.0 & 5.1 & 2.2 & 8.0 & 2.7 & 2.3 & 2.2 & 2.1 & 2.9 & 1.6 & 0.0 & 0.3 & 3.6 & 43.6 & 1589 & 1576 \\
\hline 11 & humulene epoxide & 0.0 & 1.7 & 1.2 & 1.0 & 0.6 & 1.4 & 0.6 & 0.7 & 0.6 & 0.6 & 0.6 & 0.3 & 0.0 & 0.0 & 0.7 & 45.0 & 1615 & 1581 \\
\hline 12 & bisabolone & 0.0 & 0.0 & 0.0 & 0.2 & 0.3 & 0.4 & 0.3 & 0.8 & 0.4 & 0.6 & 0.0 & 0.0 & 0.3 & 0.4 & 0.3 & 50.5 & 1717 & 1650 \\
\hline 13 & drimenol & 8.0 & 5.1 & 3.7 & 2.4 & 3.0 & 1.5 & 1.9 & 1.6 & 2.5 & 4.4 & 1.9 & 1.6 & 4.0 & 0.6 & 3.0 & 53.2 & 1770 & 1759 \\
\hline 14 & neocembrene & 0.0 & 0.4 & 0.5 & 0.3 & 0.3 & 0.5 & 0.4 & 0.3 & 0.5 & 0.2 & 0.4 & 0.2 & 0.3 & 0.0 & 0.3 & 60.7 & 1922 & 1959 \\
\hline 15 & echinoic acid & 0.0 & 3.0 & 2.8 & 1.7 & 2.2 & 1.8 & 2.6 & 3.6 & 3.1 & 1.6 & 2.7 & 2.2 & 0.3 & 2.2 & 2.1 & 63.0 & 1970 & $* *$ \\
\hline 16 & cembranoid & 3.9 & 3.7 & 4.6 & 3.4 & 4.3 & 3.2 & 3.8 & 1.8 & 2.6 & 3.1 & 5.4 & 4.1 & 1.5 & 1.7 & 3.4 & 69.8 & 2120 & - \\
\hline 17 & phytol & 12.0 & 6.6 & 2.2 & 32.2 & 45.5 & 14.4 & 40.0 & 25.5 & 16.9 & 23.9 & 17.1 & 47.5 & 11.2 & 20.0 & 22.5 & 70.2 & 2130 & *** \\
\hline 18 & $*(1-13)$ & 42.4 & 55.0 & 52.9 & 35.1 & 23.7 & 43.2 & 19.8 & 14.3 & 30.0 & 25.9 & 25.7 & 17.7 & 45.3 & 17.7 & 32.0 & - & - & - \\
\hline 19 & $(14-17)$ & 15.9 & 13.7 & 10.1 & 37.6 & 52.3 & 19.9 & 46.8 & 31.1 & 23.1 & 28.7 & 25.6 & 54.0 & 13.1 & 23.9 & 28.3 & - & - & - \\
\hline 20 & $(1-17)$ & 58.3 & 68.7 & 63.0 & 72.7 & 76.0 & 63.1 & 66.6 & 45.4 & 53.1 & 54.6 & 51.3 & 71.7 & 58.4 & 41.6 & 60.3 & - & - & - \\
\hline
\end{tabular}

* 18 = identified mono- and sesquiterpenes (1-13); $19=$ identified diterpenes (14-17); 20 = identified constituents (1-17). LRI = Adams 1995; ** = Tanaka et al. 1997; $* * *=($ C.M.A. Tanaka, unpublished data).

amount of phytol, the presence of echinoic acid as the second major component must be mentioned since it has followed the phytol variability during the fourteen months in study. The diterpenes have been biosynthesized in greater amount by the BL- population except phytol that is produced 1.6 times more by the SL-population. Comparison of variability of the two major components in the E. grandiflorus oils, phytol and $(E)$-caryophyllene, through the fourteen months of study, seems to have a sub- 

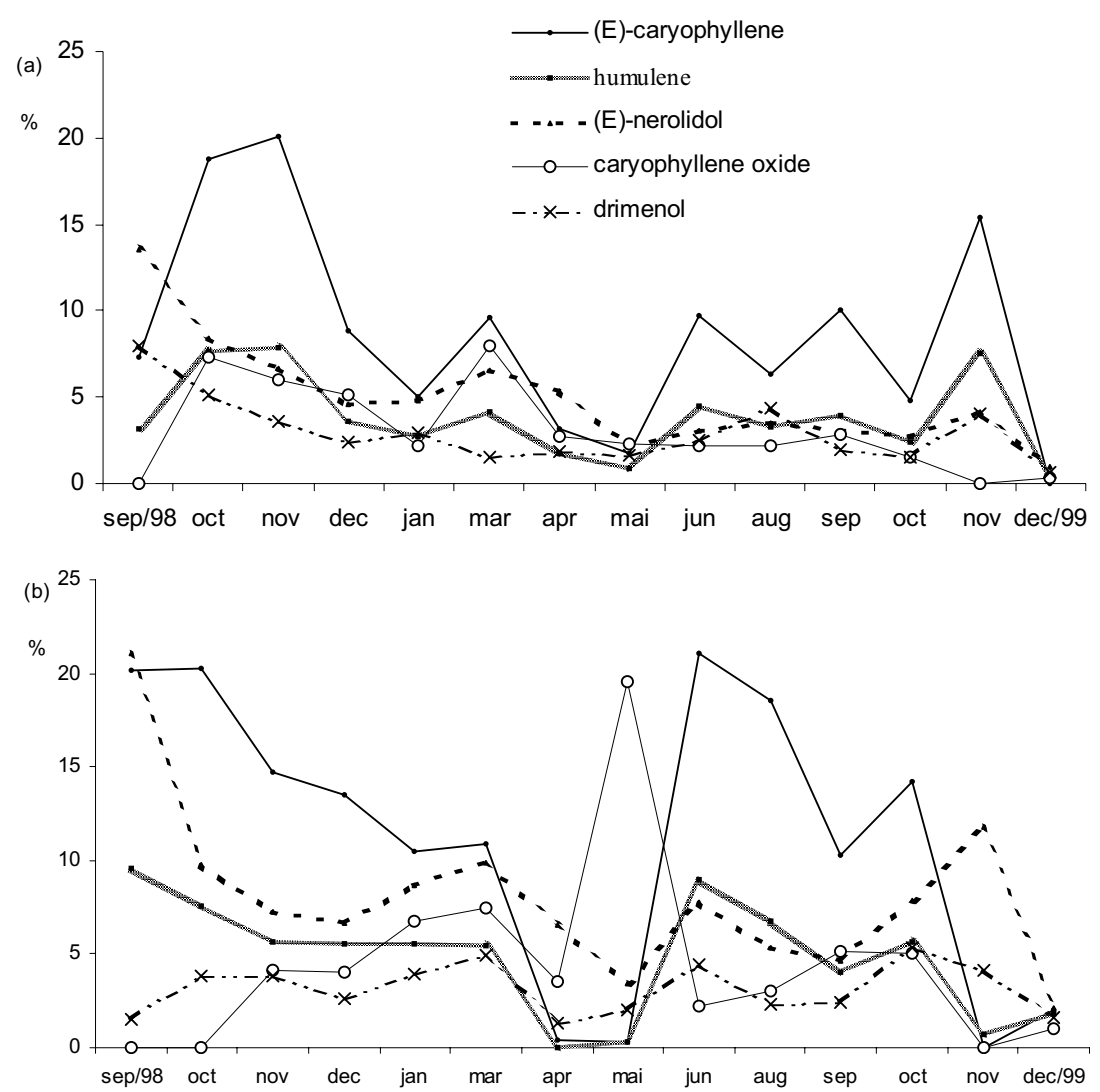

Fig. 1 - Monthly variability of the major sesquiterpene constituents of the E. grandiflorus essential oil from the SL (a) and BL (b) population (\% of chromatogram oil).

stitutive production (Figures 1 and 2).

This exuberant phytol production is of great value since this compound has been responsible for some recorded important biological activities (Pongprayoon et al. 1992, Rajab et al. 1998) which may indicates E. grandiflorus as a potential plant source for phytopharmaceuticals. In conclusion, it is worth to point out that the prominent production of phytol in both populations may characterize this compound as a chemotaxonomic marker for this plant species.

\section{ACKNOWLEDGMENTS}

The authors wish to thank Erika S. Guimarães/USP for species identification, Coordenação de Aperfeiçoamento de Pessoal de Nível Superior (CAPES),
Conselho Nacional de Desenvolvimento Científico e Tecnológico (CNPq), Fundação Oswaldo Cruz (FIOCRUZ) for financial support and Far-Manguinhos Analytical Center for chromatograms.

\section{RESUMO}

Análise por cromatografia com fase gasosa e cromatografia com fase gasosa acoplada à espectrometria de massas de óleos essenciais obtidos de folhas de Echinodorus grandiflorus ("Chapéu-de-couro") em duas diferentes populações (folhas grandes e folhas pequenas), coletadas mensalmente entre setembro de 1998 e dezembro de 1999 , revelou 17 componentes. Fitol foi o constituinte majoritário em ambas populações. Os principais representantes sesquiterpênicos foram $(E)$-cariofileno, $\alpha$-humuleno e $(E)$-nerolidol. 

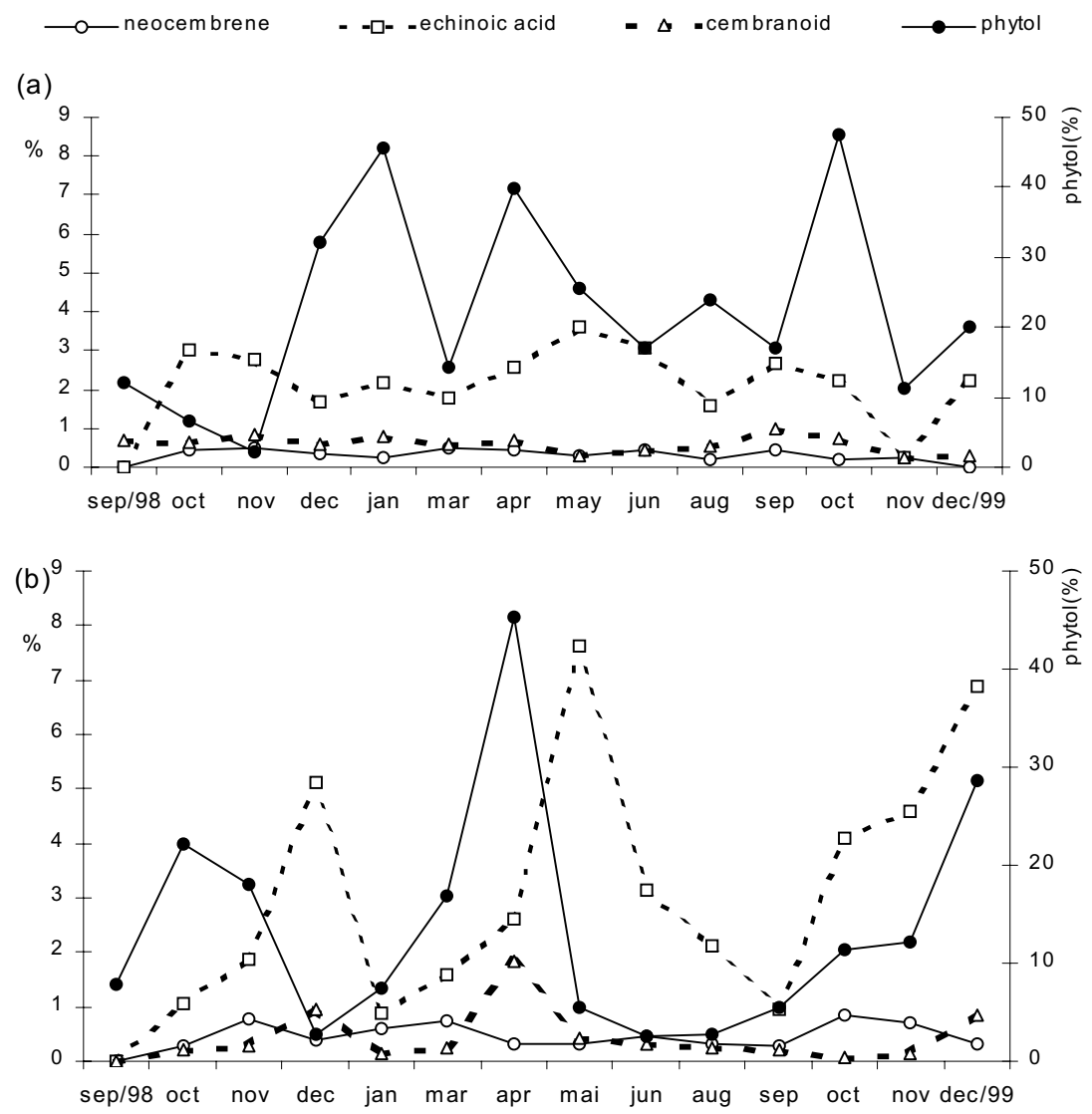

Fig. 2 - Monthly variability of the major diterpene constituents of the E. grandiflorus essential oil from the SL (a) and BL (b) populations (\% of chromatogram oil).

Palavras-chave: Echinodorus grandiflorus, Alismataceae, óleo essencial, sesquiterpenos, diterpenos.

\section{REFERENCES}

ADAMS RP. 1995. Identification of essential oil components by gas chromatography/mass spectroscopy, Illinois: Allured Publishing Corporation, $469 \mathrm{p}$.

Costa M, TANAKA CMA, IMAMURA PM AND MARSAIOLI AJ. 1999. Isolation and synthesis of a new clerodane from Echinodorus grandiflorus. Phytochemistry 50: 117-122.

CRow GE. 2003. Alismataceae: In: Manual de Plantas de Costa Rica, Hammel BE, Grayum MH, Herrera C AND Zamora N (Eds), Monographs in Systematic Botany 92, St Louis: Missouri Botanic Garden, p. 35-42.
Gottlieb OR And Magalhães MT. 1960. Modified distillation trap. Chemist-Analyst 49: 114.

HAYNES RR AND NiELSEN LBH. 1994. Flora Neotropica - Monograph 64 - The Alismataceae, New York: New York Botanical Garden, 105 p.

Kobayashi J, Sekiguchi M, Shigemori H And OHSAKI A. 2000a. Chapecoderins A-C, new labdane-derived diterpenoids from Echinodorus macrophyllus. J Nat Prod 63: 375-377.

Kobayashi J, Sekiguchi M, Shigemori H AND OHSAKI A. 2000b. Echinophyllins A and B, novel nitrogen-containing clerodane diterpenoids from Echinodorus macrophyllus. Tetrahedron Lett 41: 2939-2943.

MANNS D AND HARTMANN R. 1993. Echinodol: a new cembrene derivative from Echinodorus grandiflorus. Planta Medica 59: 465-466. 
PONGPRAYOON N, BAETSTROM P, JACOBSSON U, Lindstrom M AND Bohlin L. 1992. Antispasmodic activity of $\beta$-damascenone and E-phytol isolated from Ipomoea pes-caprae. Planta Medica 58: 19-21.

Rajab MS, Cantrell CL, Franzblau SG and FISCHER NH. 1998. Antimycobacterial activity of (E)-phytol and derivatives: a preliminary structureactivity study. Planta Medica 64: 2-4.
TANAKa CMA, SARragiotto MH, ZukermanSCHPECTOR J AND MARSAIOLI AJ. 1997. A cembrane from Echinodorus grandiflorus. Phytochemistry 44: $1547-1549$. 